\title{
Gender Mainstreaming: Policies at the National and International Level
}

\author{
Tulasa Devi Dulal (M. Phil.)*
}

\begin{abstract}
This paper tries to highlight the existing gender mainstreaming policies and practices at national and international level, to establish a clear vision and make commitments to guide the process of gender mainstreaming and women empowerment to achieve the gender equality, justice and fundamental human rights. The advancement of the rule of law at the national and international levels is thus, essential for the protection of fundamental human rights and freedom. Nepal has an obligation to take an effective action against all such malpractices. Nepal has participated and ratified the gender policies in all Conventions and conferences. To fulfill this very obligation, it has introduced some legal provisions and made an attempt to implement them. Due to this region, Nepal has started to address the gender issues from sixth five year plan to till now. Planned efforts to improve the situation of women began during the Sixth Plan (1981-1985) but its approach was welfare-driven. The Interim plan (2008-2011) focused the gender responsive budget and allocated the 33 percent reservation in every state structure. The constitution of Nepal 2015, article 11 (5) and (7) compromises the ability of women to independently confer citizenship to her child. Likewise, there are many domestic legal regimes existed here. The fifteenth periodic plan approach paper, 2020 emphasizes the gender equivalence in local level. Government policies are stated with high priorities for gender main streaming policies. The experience shows that ensuring the provisions of equal rights in the constitution is important, but at the same time, proper implementation of those provisions is equally important to balance the theoretical and practical gap of gender and development. The review follows the major discourses that influenced the gender mainstreaming agenda in the form of statements in women's movements, policy documents, laws, press materials, and experiential reflection and everyday narratives captured through existing research.
\end{abstract}

Key words: Gender policy, international conference, plan, constitution \& government act.

\section{Introduction}

Gender mainstreaming is an approach to policy-making that takes into account both women's and men's interests and concerns. The concept of gender mainstreaming was

*Ms. Dulal is a Faculty Associate of the Department of Population Studies, Patan Multiple Campus, TU, Nepal. Email: tulasadulal123@gmail.com 
first introduced at the 1985 Nairobi World Conference on Women. It was established as a strategy in international gender equality policy through the Beijing Platform for Action, adopted at the 1995 Fourth United Nations World Conference on Women in Beijing, and subsequently adopted as a tool to promote gender equality at all levels. In 1998, the Council of Europe defined gender mainstreaming as: The (re)organization, improvement, development and evaluation of policy processes, so that a gender equality perspective is incorporated in all policies at all levels and at all stages, by the actors normally involved in policy-making (CoE,1998).

Women represent almost fifty percent of the world population but simultaneously the most neglected and the poorer segment of the population. Women are financially poorer than men because mostly they are deprived of equal rights and opportunities, lack of access to the financial and economic resources and are denied social status in the society, especially in the least developed countries. So the gender related issues remain central to development debate and the poverty reduction strategies. In a number of countries, the practices of prenatal sex-selection, higher rates of mortality among young girls and lower rates of school enrollment for girls as compared to boys, child marriage, the dowry system, Chhaupadi, Deuki, and Jhuma, among others, suggest that 'son preference' is curtailing the access of girl children to food, education and health care. Keeping in view the discriminatory behavior against females, Universal Declaration on Human Rights 1948 has set some international laws (MoPE, 1996).

Similarly, international Covenant on Civil and Political Rights 1966, Convention on the Elimination of All forms of Discrimination against Women 1969, Convention on the Rights of Child 1989, etc. Furthermore, Nepal is a party to the slavery Convention 1926, Protocol Amending the slavery Convention 1953, and supplementary Convention on the Abolition of slavery, the slave trade and the institutions and practice similar to slavery 1956. All these international institutions have declared that the sale and trafficking of girls and children are illegal (UN, 2010).

Convention on the Elimination of All forms of Discrimination against Women in the preamble recalls that discrimination against women violates the principles of equality of rights and respect for human dignity, is an obstacle to the participation of women, on equal terms with men, in the political, social, economic, and cultural life of their countries, hampers the growth of the prosperity of society and the family and makes more difficult the full development of the potentialities of women in the service of their countries and of humanity. In this context the society in Nepal is not an exception. 


\section{Objectives}

The overall objective of this study is to review the international and national laws, policies and practices regarding gender mainstreaming agenda. The specific objectives of this study are to review the policy acts and conventions at international level and to examine the major gender laws and policies enacted by the constitution of Nepal.

\section{Methodology}

This study primarily builds upon desk reviews of policy acts, United Nation Conventions, journal papers and grey articles. The desk review follows the major discourses that influence the gender mainstreaming agenda in the form of statements in policy documents, women's movements, constitutions, laws, press materials, and experiential reflection and everyday narratives captured through existing research.

\section{Interpretation and Analysis of the Results}

\section{International Policy Agenda}

In the international practices, discrimination based on sex is prohibited under almost every human rights treaty. The International Covenant on Civil and Political Rights and the International Covenant on Economic, Social and Cultural Rights, which under their common Article 3 provide the rights to equality between men and women in the enjoyment of all rights. In addition, the Convention on the Elimination of all forms of Discrimination against Women is dedicated to the realization of women's human rights. Considered the international bill of rights for women, the Convention defines what constitutes discrimination against women and sets an agenda for national action to end such discrimination. Nepal has participated in the formulation of a variety of international human rights instruments which have an impact on children and women is a party to a number of them.

As discussed earlier, the women's right covers wide range of human rights issues. Consequently, one cannot confine oneself within the particular human rights law. However, for the women's rights we have the explicit document the Women Right Declaration. Similarly, the Rio Conference on the Environment and Development 1992, the Vienna Declaration 1993, World Summit for Social Development 1994, Beijing Conference 1995, and Millennium Development Goals 2000 have also explicitly mentioned the women's right as several multitudes of social, economic, political, environmental and cultural spheres that have critical relationship with women as being (UN,1995). Beijing Conference 1995 has identified 12 critical areas of concerns and the Platform of Action adapted to response to those critical areas providing the guidelines to work for better 
socio-economic status the human rights (Pokharel, 2015).

The term "discrimination against women" means any distinction, exclusion or restriction made on the basis of sex which has the effect or purpose of impairing or nullifying the recognition, enjoyment or exercise by women, irrespective of their marital status on the basis of equality of men and women of human rights and fundamental freedom in the economic, social, cultural, civil, political or any other field (CEDAW, 1999).World conference on women and development, Copenhagen July 1980 decided the UN decade for women (1976-85). Delegations from 45 nations come together in Copenhagen to review progress on the 1975 World plan of Action and to promulgate a program of action for the second half of the decade for women.

The Convention on the Elimination of All Forms of Discrimination against women was adopted by the general assembly of UN in 1979 and had 165 states parties as of January 2000. The convention seeks to address pervasive social, cultural and economic discrimination against women, declaring that state should endeavor to modify social and cultural partners of conduct that stereotype either sex or put women in and interior position. It also declares that state should ensure that women have equal rights in education and equal access to information; eliminate discrimination against women in access to health care and end discrimination against women in all matters relating to marriage and family relations. The convention declares that state must act to eliminate violations of women rights whether by private persons, groups or organizations (UNFPA, 2000).

The 1994 International Conference on Population and Development raised the issue of empowering women and improving their status as important agenda as it is essential for achieving sustainable development. Principle 4 of the International Conference on Population and Development program of action states advancing gender equality and equity and empowerment of women, and the elimination of all forms of violence against women and ensuring women's ability to control their own fertility are cornerstones of population and development-related program. The human rights of women and the girl child are inalienable, integral and indivisible part of universal human rights. The full and equal participation of women in civil, cultural, economic, political and social life at the regional, national and international level and eradications of all forms of discrimination on grounds of sex are priority objectives of the international community (UNFPA, 2010).

Another landmark event in efforts to achieve full equality for women was the Fourth World Conference on Women held in Beijing in 1995. The Beijing platform identifies '12 critical areas' of action needed to empower women and ensure their rights. Women and poverty, education and training of women, women and health, violence against women, 
women and armed-conflict, women and the economy, women and power and decision making; institutional mechanisms for the advancement of women, women and the media, women and the environment and the girl child. The Fourth World Conference on Women reaffirmed and strengthened the consensus that had emerged at the International Conference on Population and Development in Cairo the year before (Pokharel, 2005). After the Beijing conference, the Ministry of Women and Social Welfare, established in 1995, was renamed the Ministry of Women, Children and Social Welfare in 2000.

The world conference on Human Rights held in Vienna in 1993 urged that increased priority be given to eradicating all forms of discrimination on grounds of sex. Nepal has reaffirmed its recommendations to the 1995 Beijing declaration on women's equality, development and peace, including implementing the platform for action adopted by the Fourth World Conference on Women. It urged Nepal to amend discriminatory laws on property and inheritance, marriage, nationality, birth registration, abortion and to punish persons who procure women for prostitution or for trafficking and expressed concern about harmful traditional customs and practices such as child marriage, dowry, polygamy, and ethnic and religious practices that force girls to become prostitutes (UNFPA, 2010).

Likewise, International Conference on Population and Development plus 5, International Conference on Population and Development plus 10, and Millennium Development Declaration 2000, have made various programs and policies to enhance the women's life. Nepal, as the signatory country of these conferences and conventions, has made some positive changes and has slightly increased in women participation in decision making but it is not improving in satisfactory manner. (BBC, 2004).

After a long struggle of women rights merged to the surface since the beginning of the 20th century, the UN adopted the Convention on women's political rights in 20 December 1952 and the Convention on Elimination of all forms of Discrimination Against women on December 1979, which came into force on 3 September 1981. Nepal becomes state party to the former on 20 April 1966 and to the later on 22 April 1991.

Nepal has used 'monastic approach' in giving legal validity to the international rights. Under this approach, once ratified, the treaty automatically becomes the law of the ratifying state and prevails over any domestic legal provisions inconsistent with the international instrument (conventions). Those conventions (such as Convention on the Elimination of all forms of Discrimination Against Women) provide 'general recommendations' to assist state parties in understanding more intricate meanings and intent of the articles of the convention (Giri, 2012). 


\section{Abortion Right}

From the medical point of view, abortion is the termination of pregnancy and is legal under some circumstances in Nepal. Abortion is, however, punishable if performed without the consent of the pregnant women. There is no restrictive policy or norms of the government on the number of child. For years, Nepal banned abortion under any circumstance, and did not explicitly permit it even to save a woman's life or in cases of unwanted pregnancy resulting from rape or incest. Abortion was equated with infanticide, and with other kinds of murder or homicide, and many women were routinely thrown into prison for having abortions, and many died from unsafe abortion procedures. Women who sought abortions did so clandestinely with the providers (Shakya, 2004).

Efforts to liberalize the abortion law in Nepal began in the 1970s; however, discourse surrounding the reform was contrastingly different. In 1970s, abortion has been largely discussed as an effective method of regulating fertility. Government of Nepal, with assistance from the US, initiated two national level, consensus-building conferences on the need to regulate population growth through maternal and child health program. Family Planning Association of Nepal.

Family Planning Associotion of Nepal (FPAN)-an affiliate of the International Planned Parenthood Federation, together with program managers, providers and policymakers representing the public and private sectors discussed the medical rationale and relevance of making abortion legally accessible and available to women with unwanted pregnancies (Giri, 2012).

\section{Table : Legal and policy framework for abortion rights in Nepal}

\section{Abortion Law in Nepal}

Only listed (trained) doctors or health workers can provide safe abortion services at listed (approved) health facilities, under the following conditions:

- Legal up to first 12 weeks of pregnancy for any woman with woman's voluntary consent. The permission of husband or guardian is not required for women above 16 years of age.

- Legal up to first 18 weeks of pregnancy in cases of rape and incest

- Legal anytime if the pregnancy poses danger to the life of the pregnant woman or to her physical or mental health or if it leads to the birth of a disabled child.

- Illegal on the basis of sex identification.

The Constitution of Nepal 2072 has declared the fundamental rights of women in article 
38. According to this provision, safe motherhood and reproductive health, protection of GBV (any physical, mental, sexual or psychological or any other kind of violence against women or any kind of oppression based on religious, social and cultural tradition, and other practices) are introduced. Similarly, right to access participation in all state structures and bodies on the basis of the principle of propositional inclusion is also guaranteed by the Constitution. Special opportunities are provided by the Constitution for the minority's groups in every sphere of education, health, employment and social security on the basis of positive discrimination (GoN, 2015). Article 11 (5) and (7) compromises the ability of women to independently confer citizenship to her child as the father of the child must be unidentified or to claim citizenship by descent; in cases where a Nepali women is married to a foreigner she may only confer naturalized (not descent ) citizenship (GoN, 2073).

\section{Nepalese Government's Periodic Plan and Policies on Gender}

Nepalese government's laws and policies on gender in its development endeavor initiated since its first five year Plan (1956-1961). Nevertheless, during that period the state policy on women was formulated with a "welfare approach" focusing on the reproductive role of women as mothers and homemakers. A shift in the focus on women occurred during mid and late 1970s with Nepal observing the International Women's Year and participating in the First World Conference on Women in 1975; and the subsequent study on the Status of Women in Nepal 1979 (Bhadra and Thapa, 2007).

Sixth five-year Plan (1980-85) initiated the WID (Women in Development) policy assigning a separate chapter about the role of women in development, which was followed by the seventh five-year Plan (1985-1990) and the eighth five-year plan (1992-1997). Sixth Plan adopted an "efficiency approach" to women in development recognizing the productive role of women for the first time in Nepal's planned development. The seventh plan adopted a "(equal) participatory approach" along with the efficiency approach and the eighth plan adopted an "equity approach" along with a realization of the need to mainstreaming women in development (Bhadra, 2007).

A paradigm shift occurred from women in development to gender and development (gender and development) in Nepal's development policy during the ninth five-year plan (1997-2002), which is given continuation in the tenth five-year plan (2003-2008). These Periodic Plans have adopted the policy of "gender equality" and "women's empowerment" by adopting the strategy of "gender mainstreaming".

The tenth five-year plan (2003-2008), which is also the Poverty Reduction Strategy Paper (PRSP), identified gender equality as the major indicator of poverty analysis. Gender 
budget audits have been completed in the Ministries of agriculture (2002), health (2002), education (2002), local development (2003) and Women, Children and Social Welfare (2003). Also in place are gender disaggregated indicators and a monitoring mechanism is being put in place to measure the outcomes in the Ministry of Women, Children \& Social Welfare named "Women and Child Info"2004 (NPC, 2007).

Planned efforts to improve the situation of women began during the Sixth Plan (19811985) but its approach was welfare-driven. Sixth five-year plan (1980-85) initiated the WID (Women in Development) policy assigning a separate chapter about the role of women in development.

Likewise, the eighth plan spoke about increasing women's representation in decisionmaking and also introduced the idea of 'gender' based 'discrimination'-but did not define either term. The ninth plan used gender as a synonym for women but, like earlier plans, lacked operational guidelines. The tenth plan focused the poverty reduction strategy paper was the most serious and comprehensive government statement about inclusion to date. It identifies social exclusion as one of the three main aspects of poverty and the main reason for deprivation of certain caste and ethnic groups, women and people living in remote areas.

The Interim plan (2008-2011) focused the gender responsive budget and allocated the 33 percent reservation in every state structure. The fifteenth periodic plan approach paper 2020 emphasizes the gender equivalence in local level. To implement the constitution of Nepal 2015 and to achieve the Sustainable development Goals. Similarly, laws regarding the violence against women have also been passed in the constitution by the current government. It recognizes lack of voice, political representation and empowerment as important dimensions of poverty that are linked to economic and human development poverty.

Nepal's Constitution does not permit discrimination on the basis of sex and advocates special legal provisions to protect and advance the interests of women. The local selfgovernance act 1999 also introduced mandatory representation of women in local government. However, women's representation declines progressively at higher decisionmaking levels where they are outnumbered. Elected local bodies were suspended in July 2002, resulting also in the suspension of the representation requirements of the local selfgovernance act (Giri, 2012).

Various formal and informal approaches should be applied to exercise equal rights and opportunities. This should include the effective implementation of the Constitution 
through the formation of proper laws with enforcement mechanisms. Differential treatment and positive discrimination, advocacy aimed at changing mindsets, beliefs, norms and practices towards women can help to practically rebalance the power.

\section{Discussion}

Gender parity is central point of inclusive development addressing global agenda 2030 and linking with local issues for sustainable development. This work has explored international instruments - Universal Declaration of Human Rights - for gender parity in local level development like federal mechanism in Nepal where newly federal administrative structures has been promulgated after comprehensive peace accord in 2006 and new constitution.

Various conferences and conventions emphasized the gender main-streaming policies widen its areas of concerns in several multitudes of social, economic, political, environmental and cultural spheres that have critical relationship with women as being. Nepal has a signatory to almost all of the international conventions on human rights, women rights, and children rights as well as to agreements on international goals regarding education, health and poverty eradication. As a signatory to the Convention on the Elimination of All forms of Discrimination Against Women adopted in 1979 by the United Nations General Assembly, the government of Nepal promises non-discrimination, gender equity, and social justice as mandated by the 2015 Constitution of Nepal.

After the big political change of 2006, government of Nepal has been trying to make more participation and empowerment in local development entire planning process to all the phase of development. The interim Constitution emphasizes on allocating 33 percent of seats for women in political sector for both the first-past-the-post system and for the proportional representation system. During the elections, all political parties nominated female candidates only for the proportional seats. Only a few female candidates were elected through the First Past the Post system. This again helped place men in decisionmaking positions and places.

Recent local elections held in 2017 saw 753 Deputy Mayors/Chairs from 6 metropolitan cities, 11 sub metropolitan cities, 276 municipalities and 460 rural municipalities elected. The fact that 700 of these were female is a major achievement. If you look at the details though, out of 753, only 18 of the elected Mayors/chairs were female. The question is, why were only 18 female Mayors/Chairs elected out of 753 seats? 
Government policies are stated with high priorities for women empowerment. However, without women participation in planning we can't implement our development program effectively. Accepting international instrument like gender parity and conceiving the essence of the instrument in local law and policies are visible element to push forward global agenda respecting liberalism in new dynamics for change. The experience shows that ensuring the provisions of equal rights in Constitution is important, but at the same time, proper implementation of those provisions is equally important to balance the theoretical and practical gap of gender development. Principally, almost development activities are focused on women, children and other socio-economically disadvantaged communities but those given priorities are almost limited on policy document only gender needs are most to be addressed in local level.

\section{Conclusion}

This study finds that, various conferences which are mainly focused on women issues. Nepal has participated and ratified the all Conventions and conferees. Due to the reason, Nepal has addressed the gender issues from sixth five year plan to till now. Planned efforts to improve the situation of women began during the Sixth Plan (1981-1985) but its approach was welfare-driven. The Interim plan (2008-2011) focused the gender responsive budget and allocated the 33 percent reservation in every state structure. The fifteenth periodic plan approach paper, 2020 emphasizes the gender equivalence in local level. The Ministry of Local Development (MLD) was first to incorporate gender issues in programming when it set up the Women's Development Section (WDS) in the early eighties.

Nepalese Government amended the laws and policies in constitutions. The Interim Constitution 2006, emphasized on allocating 33 percent of seats for women in political sector and in all the state structure. The constitution of Nepal 2015, article 11 (5) and (7) compromises the ability of women to independently confer citizenship to her child as the father. The truth is that formal equality is enough, as women and disadvantaged groups are not on equal footing to utilize these formal opportunities. Adaptation strategy and implementation of gender parity is in manifold of outfit of the study which also connects roles and responsibilities of development actors and authority in local level. 


\section{References}

Bennett, L. (2005). Gender, caste and ethnic exclusion in Nepal: Following the policy process from analysis to action, paper presented at the Arusha Conference, London.

Beyond Beijing Committee (BBC). (2004). Alternative advocacy NGO CEDAW lobby document on second and third periodic report on CEDAW 2004. Beyond Beijing Committee, Kathmandu, Nepal. https://www.beyondbeijing.org/

Bhadra, C. \& Thapa, S. M. (2007). Nepal country ender profile. A final report. https://www.jica.go.jp/ activities/issues/gender/reports/ku57pq00002hdv3w-att/nep_2007_en.pdf

Convention on the Elimination of Discrimination Against Women (CEDAW). (1999). Optional protocal to the convention on the elimition of all forms of Discrimination against Women. https://www.refworld.org.

Council of Europe (CoE). (1998). Gender mainstreaming at the council of Europe: Avenue de 1' Europe F-67075 Strasbourg Codex, France.

Government of Nepal (GoN). (2015).Constitution of Nepal 2015: Constitutional assembly secretarial. Singh Durbar, Kathmandu: Nepal Law Commission. https://www info@lawcommission. gov.np.

Giri, K. (2012). Gender reforms in Nepal: Retreat or predicaments? A review of the politics and practice of women's rights. Alliance for Social Dialogue and South Asia Institute of Advance Studies. Kathmandu, Nepal.

Government of Nepal (GoN). (2063). The interim constitution of Nepal 2006. Kathmandu: Singh Durbar, Nepal

Interim Constitution (IC). (2063). The interim constitution of Nepal 2006, Kathmandu: Law Book Commission, Nepal.

Khanal, R. (2003). Local self-government in Nepal. A study of democracy at the grass-roots 19902000. (Unpublished dissertation for the degree of doctor of philosophy in political science) Tribhuvan University, Kathmandu, Nepal.

Law Books Management Committee (LBMC). (2047). The constitution of the kingdom of Nepal. Kathmandu: Nijamati Kitab Khana, Nepal.

Ministry of Law (MoL) (2055). Local self-government act 1991. Kathmandu: Ministry of Law, Nepal. https://www.lawcommission.gov.np/en/wp-content/uploads/2018/10/local-selfgovernance-act-2055-1999.pdf

Ministry of Population and Environment (MoPE). (1996). Final report for reviews of laws related to population sector and recommendation. Kathmandu: Ministry of Population and Environment, Nepal.

Ministry of Science, Technology \& Environment (MoSTE). (2010). Gender equality and social 
inclusion toolbox, promotion for renewable energy technologies, Kathmandu: Alternative Energy Promotion Center. Government of Nepal, Nepal.

National Human Right Commission (NHRC). (2053). Human right in Nepal status report 2003. Lalitpur: National Human Right Commission. Harihar Bhawan, Pulchowk, Lalitpur, Nepal.

National Planning Commission (NPC). (2003). The tenth five year plan 2003-2008. Kathmandu: His Majesty's Government. National Planning Commission Secretary, Nepal.

National Planning Commission (NPC). (2006). An assessment of the implementation of tenth plan: PRSP Review 2004-2005. Kathmandu: National Planning Commission Secretary, Singh Durbar, Nepal.

National Planning Commission (NPC). (2007). Three years interim plan. Kathmandu: National Planning Comission Secretary, Singh Durbar https://www.npc.gov.np>images>categories.

Pokharel, K. (2005). The right to development: Contributing in minimizing conflict with reference to Nepalese perspective. (Unpublished LLM Thesis). Kathmandu School of Law, Purbanchal University, Bhaktapur, Nepal.

Pokharel, C. M. (2015). Participation of women in household decision making process: A case study of Prapcha VDC of Okhaldhunga district. (Unpublished Master's Thesis). Central Department of Population Studies, Tribhuvan University, Kathmandu, Nepal.

Pradhan, S. M. (2003). Inheritance rights of Nepali women: Journey towards equality. Forum for Women, Law and Development. Singh Durbar, Kathmandu, Nepal

Shakya, G., Sabitri K., Cherry B., \& Jennifer B. (2004). Abortion law reform in Nepal. Women 's Right to Life and Health. 12 (24), Supplement, Reproductive Health Matters, Kathmandu, Nepal.

United Nations Fund for Population Activities (UNFPA). (2000). Gender equality. UNFPA-United Nations Population Fund. https://www.unfpa.org>gender equality.

United Nations (UN). (1995). Bejing Declarations the United Nations. http://www.unwomen. org $>$ incocus $>$ csw59 faturs stories.

United Nations (UN). (1990). Population and human rights, proceeding of the expert-group meeting on population and human rights. Geneva, Switzerland.

United Nations (UN). (1949). Concept of human Rights in International Law, 82 column. L. Rev. 1110(1949).

United Nations(UN).(2010). A case study to makestate accountable towards effective implementation of the CEDAW convention. Status Review, A1 Nations Development Programme, Kathmandu, Nepal.

United Nations Population Fund (UNFPA). (2010). Gender equity and empowerment in Nepal. Kathmandu, Nepal. 